\title{
Multicenter validation of a mouse model for cow's milk allergy to assess the allergenicity of hydrolysed cow's milk based infant formulae
} \author{
LMJ Knippels ${ }^{1,2}$ \\ From Food Allergy and Anaphylaxis Meeting (FAAM 2013) \\ Nice, France. 7-9 February 2013
}

BCAM van Esch ${ }^{1,2}$, JHM Van Bilsen ${ }^{3 *}$, PV Jeurink ${ }^{2}$, J Garssen ${ }^{1,2}$, KCM Verhoeckx ${ }^{3}, J J$ Smit $^{4}$, RHH Pieters ${ }^{4}$,

\section{Background}

The EC-directive 2006/141/E requires objective and scientifically verified data to claim hypoallergenicity of hydrolysed formulae. However, no validated animal models are currently available to assess the residual sensitising capacity, although guinea pig assays are frequently used. This study is part of a multi-phase project which aims to validate a recently developed mouse model to assess the potential allergenicity of hydrolysed cow's milk based infant formulae. The discriminatory power of a mouse allergy model for cow's milk allergy to distinguish sensitizing properties of cow's milk products was evaluated in 4 independent research centers.

\section{Methods}

$\mathrm{C} 3 \mathrm{H} / \mathrm{HeOuJ}$ mice were sensitised by oral administration of whey (WPC80) or extensively hydrolysed cow's milk $(\mathrm{eWH})$ at weekly intervals for 5 weeks. One week after the last sensitisation, the acute allergic skin response (ear swelling at $1 \mathrm{hr}$ ), anaphylactic symptoms and temperature were determined upon intradermal ear injection of whey. Subsequently, mice were challenged orally with $50 \mathrm{mg}$ whey and blood samples were taken after $30 \mathrm{~min}$. Serum was analyzed for whey-specific immunoglobulins and $\mathrm{mMCP}-1$. All protocols, test substances and procedures were standardised.

\section{Results}

All participating research laboratories detected elevated levels of whey-specific IgE/IgG1/IgG2a, serum mMCP-1 (reflection of mast cell degranulation) and acute allergic

${ }^{3} \mathrm{TNO}$, Zeist, the Netherlands

Full list of author information is available at the end of the article skin responses in whey sensitised animals. Anaphylactic symptoms and temperature drop were scored in 3 out of 4 research centers. In contrast, none of the evaluated parameters was altered in eWH-sensitized groups as compared to the vehicle control group.

\section{Conclusion}

All 4 independent research centers were able to discriminate between the sensitising properties of whey protein and extensively hydrolysed cow's milk. The results demonstrate the discriminatory power of the mouse model and thereby the suitability of the mouse model to evaluate the allergenicity of hydrolysed cow's milk formulae. In the next phase of the multicenter validation process, partially hydrolysates will be included to assess the sensitivity of the discriminatory power of the mouse model.

\section{Disclosure of interest}

B van Esch: Employee of Danone Research Centre for Specialised Nutrition, J Van Bilsen: None declared, P Jeurink: Employee of Danone Research Centre for Specialised Nutrition, J Garssen: Employee of Danone Research Centre for Specialised Nutrition, K Verhoeckx: None declared, J Smit: None declared, R Pieters: None declared, L Knippels: Employee of Danone Research Centre for Specialised Nutrition.

\footnotetext{
Author details

${ }^{1}$ Utrecht Institute for Pharmaceutical Sciences, Utrecht, the Netherlands. ${ }^{2}$ Danone Research Centre for Specialised Nutrition, Wageningen, the Netherlands. ${ }^{3} \mathrm{TNO}$, Zeist, the Netherlands. ${ }^{4}$ Institute for Risk Assessment Sciences, Utrecht, the Netherlands.
} 
doi:10.1186/2045-7022-3-S3-P142

Cite this article as: van Esch et al:: Multicenter validation of a mouse model for cow's milk allergy to assess the allergenicity of hydrolysed cow's milk based infant formulae. Clinical and Translational Allergy 20133 (Suppl 3):P142

Submit your next manuscript to BioMed Central and take full advantage of:

- Convenient online submission

- Thorough peer review

- No space constraints or color figure charges

- Immediate publication on acceptance

- Inclusion in PubMed, CAS, Scopus and Google Scholar

- Research which is freely available for redistribution 